\title{
PENYELESAIAN SENGKETA PADA AKAD MURABAHAH DENGAN PENDEKATAN NON LITIGASI DI KSPPS BTM MULIA BABAT LAMONGAN
}

\author{
Muhammad Fahmi Azis \\ Isma Swadjaja \\ Universitas Muhammadiyah Surabaya \\ Email: fahmiazis1995@gmail.com
}

\begin{abstract}
Disputes are disputes, disputes or disputes that occur between one party and another related to valuable rights in the form of money or property.

Shari'ah economic disputes are the domain of disputes in business or trade activities. Shari'ah economic disputes can occur before or after the agreement is agreed, for example regarding the object of the agreement, the price of goods, and the contents of the agreement (Akad).

In this case, this research focuses on the resolution of non-litigation sharia economic disputes on the murabahahh contract and the application of the murabahahh contract in Bspm Mulia Babat.

This research is a descriptive qualitative research is a research method to make a picture of a situation or event, so that it is desirable to hold the accumulation of basic data using the method of observation, interviews, and documentation. The results of the study are that the resolution of non-litigation sharia economic disputes in the murabahahh contract in the compt btm noble tripe uses the system of family, peace, deliberation (sulhu) and the application of murabahah contract in accordance with Islamic economic principles and principles.
\end{abstract}

Keywords: Dispute Resolution, Non Litigation and Murabahahh Agreemen

\section{PENDAHULUAN}

Perkembangan dunia perekonomian yang semakin pesat membuat semua industri ataupun lembaga keuangan ikut terpengaruh dalam hal pengelolaan dan pengalokasian masyarakat. Selain itu lembaga keuangan juga berfungsi untuk membantu usaha masyarakat baik usaha kecil maupun usaha menengah keatas. Seiring bertambahnya manusia yang membutuhkan jasa lembaga keuangan, maka semakin pesat pula pertumbuhan lembaga keuangan tersebut.

Indonesia adalah negara berkembang yang sedang melakukan berbagai pembangunan di segala bidang kehidupan. Perekonomian merupakan salah satu bidang yang sangat penting dalam meningkatkan taraf hidup untuk mencapai masyarakat Indonesia yang sejahtera, adil, dan makmur sesuai citacita bangsa Indonesia. Perekonomian juga merupakan indikator majunya suatu negara. Oleh karena itu, Pemerintah perlu memberikan kesempatan yang seluas-luasnya bagi seluruh lapisan masyarakat, khususnya di kalangan pengusaha dan investor asing maupun domestik untuk mengembangkan kegiatan usahanya dan menciptakan lapangan kerja di Indonesia ${ }^{1}$.

Undang-Undang Nomor UndangUndang Nomor 21 Tahun 2008 pasal 1 ayat 3 mengenai bank Syariah adalah bank yang menjalankan kegiatan usahanya berdasarkan Prinsip Syariah dan menurut jenisnya terdiri atas Bank Umum Syariah dan Bank Pembiayaan Rakyat Syariah. Pada Bank syariah, dalam menjalankan kegiatan banknya menerapkan prinsip-

\footnotetext{
${ }^{1}$ Anggun Inggriani, Pembiayaan al-Murabahah pada Bank Mandiri Syariah, (ThesisUniversitas Indonesia, Depok, 2011), 3.
} 
prinsip syariah berdasarkan agama Islam dengan pembagian keuntungan secara bagi hasil. Bank syariah ini cukup berkembang pesat dan diminati di Indonesia yang mayoritas beragama Islam².

Akad murabahah dikalangan masyarakat Indonesia sangat tinggi peminatnya, hal ini karena akad murabahah mudah dipahami masyarakat atau calon nasabah. Akad murabahah merupakan akad jual beli yang dilakukan oleh lembaga keuangan dengan nasabah dimana lembaga keuangan menjelaskan kepada nasabah terkait harga awal dan margin yang didapat lembaga ${ }^{3}$. Menurut Ahmad Azhar Basyir, akad adalah suatu perikatan antara ijab dan qabul dengan cara yang dibenarkan syara' yang menetapkan adanya akibat-akibat hukum pada obyeknya ${ }^{4}$.

KSPSS BTM Mulia Babat merupakan salah satu wujud kepedulian lembaga keuangan dalam meningkatkan dan menyejahterakan ekonomi masyarakat. BTM Mulia Babat tersebut menawarkan pembiayaan dengan akad murabahah, baik itu pembiayaan untuk keperluan konsumtif, investasi maupun produktif, pengadaan barang atau jasa. Secara umum nasabah mengajukan permohonan pembelian suatu barang, dimana barang tersebut akan dilunasi oleh pihak bank syariah kepada penjual. Sementara nasabah bank syari'ah melunasi pembiayaan tersebut kepada bank syariah dengan menambah sejumlah margin kepada pihak bank syariah dengan perjanjian murabahah yang telah disepakati sebelumnya antara nasabah dengan bank syariah. Setelah itu pihak nasabah dapat melunasi pembiayaan

\footnotetext{
2"Ibid"

${ }^{3}$ Ikit dan Artiyanto, Jual Beli Dalam Prespektif Ekonomi Islam, (Yogyakarta: Gava Media, 2018), 144.

${ }^{4}$ Bagya A. Prabowo, Aspek Hukum Pembiayaan Murabahah pada Perbankan Syariah,(Yogyakarta: UII Press, 2012), 47
}

tersebut baik secara tunai maupun dengan cara angsuran ${ }^{5}$.

Praktik akad murabahah pada umumnya kembali kepada masing-masing Bank, namun di BTM Mulia Babat bisa menyediakan modal dan juga barang kepada nasabah, Dalam praktiknya, implementasi akad murabahah yang diterapkan untuk modal usaha dilaksanakan seperti akad mudharabah dengan adanya tambahan akad wakalah (perwakilan) pada pembiayaan tersebut. Pembiayaan murabahah dilaksanakan dalam satu transaksi dengan wakalah, yaitu pemberian kekuasaan pada nasabah untuk membeli barang yang diinginkan secara mandiri. Hal ini tentunya bertentangan dengan sistem murabahah pada umumnya, dimana subyek penjualan (barang atau komoditas) hendaknya memiliki penjual (bank) dan penjual seharusnya mampu mengirimkannya kepada pembeli (nasabah). Dengan tambahan akad wakalah, posisi BTM bukan lagi sebagai perantara antara pembeli dari pemasok dan menjualnya kepada nasabah melainkan hanya sebagai shohibul mal yang meminjamkan dananya untuk nasabah.

Posisi BTM Mulia Babat hanya menyediakan modal saja bukan barang yang dibutuhkan nasabah. Sedangkan pihak BTM menuntut untuk mendapatkan keuntungan (margin) hasil pembelian barang yang dilakukan nasabah.

Meskipun sudah menerapkan prinsipprinsip syari'ah dalam menjalankan transaksinya. Perekonomian syari'ah tidak luput dari masalah baik akad, wan prestasi, jasa ada yang cacat bahkan sampai ke rana peradialan akibat sengketa ekonomi syari'ah. Sengketa ekonomi masih banyak ditemui diberbagai BUS atau UUS dan perbankan syari'ah lainnya. Dari segi akad, baik akad mudharabah, akad tijarah, akat musyarakah, akad musyarakah dan

\begin{tabular}{lrrr}
\hline${ }^{5}$ Latifatul Hanik & Barokah, & Analisis \\
pelaksanaan Akad & Murabahah Untuk \\
Pembiayaan Modal Usaha Di Baitul Mall Wa \\
Tamwil Istiqomah Karangrejo Tulung Agung, \\
(Skripsi-IAIN Tulung Agung, 2015),
\end{tabular}


lainya, dari segi produknya juga masih banyak yang kurang maksimal serta menurunnya tingkat kepercayaan masyarakat.

Dengan banyaknya masalah sengketa ekonomi syari'ah maka Mahkama Agung juga memberikan wadah untuk pengaduan dalam menyelesaikan perkara sengketa. Dapat dikatakan bahwa kewenangan penyelesaian sengketa ekonomi syari'ah di Pengadilan Agama relatif baru, pasca lahirnya Undang-undang Nomor 3 Tahun 2006 Amandemen Terhadap Undangundang Nomor 7 Tahun 1989 Tentang Peradilan Agama, perkara Ekonomi syari'at mengalami lonjakan. Lonjakan terjadi karena faktor kepercayaan masyarakat terhadap keabsolutan putusan pengadilan agama. Di sisi lain, dengan lahirnya Putusan Mahkamah Konstitusi Nomor 93/PUU-X/2012 tentang pengujian terhadap undang-undang nomor 21 tahun 2008 tentang Perbankan Syariah yang menghapus dualisme lembaga peradilan dalam menyelesaikan sengketa ekonomi syariat $^{6}$. Namun, dalam perjalanannya, pada tahun 2008 diterbitkan UU NO. 21 Tahun 2008 tentang Perbankan Syariah. Penjelasan Pasal 55 ayat 2 UU Perbankan Syariah menyatakan bahwa apabila terjadi persengketaan perbankan syariah selain diselesaikan di pengadilan agama juga dapat diselesaikan di pengadilan umum sehingga terjadi dualisme pengaturan penyelesaian sengketa ekonomi syariah. Ketidakharmonisan undang-undang ini akhirnya diselesaikan dengan putusan $\mathrm{MK}^{7}$ No. 93/PUU-X/2012.

Sengketa ekonomi salah satunya bisa terjadi akibat wanprestasi salah satu pihak baik nasabah atau perbankannya. Melihat konteks akad yang dipakai kedua belah pihak, belakangan ini banyak sekali

\footnotetext{
${ }^{6}$ Amran Suaidi, Penyeleseian Sengketa Ekonomi Syar'ah (Jakarta: Prenada Media Group), 2018.

7 Mulyadi, pengadilan agama berwenang memeriksa sengketa ekonomi syari'ah. Kompasia beyond blogging. Diakses pada tanggal 3 desember 2019.
}

koprasi atau perbankan syari'ah mengalami sengketa ekonomi salah satunya akad syari'ah. Penyeleseian sengketa ekonomi terdapat beberapa cara melalui litigasi maupun non litigasi. Sengketa adalah pertentangan, perselisihan,atau percekcokan terjadi antara dua pihak yang satu dengan yang lainnya yang berkaitan dengan hak yang bernilai, baik berupa uang atau benda[8].

Pada akad ekonomi tidak bisa lepas dari sengketa, diantaranya terjadi pada akad murabahah. Kebanyakan masalah murabahah adalah macetnya cicilan yang harus dibayar oleh nasabah kepada bank yang membantu atau memodali usahanya. Murabaha sendiri lebih fokus pada jual beli yang mana keuntungannya disepakati dari kedua belah pihak yang bersangkutan. Penyelesaian sengketa ekonomi syariah pada akad murabahah di KSPPS BTM Mulia Babat masih bisa ditempuh dengan jalur kekeluargaan. Penyelesaian sengketa dengan kekeluargaan merupakan penyelesaian diluar peradilan semacam Arbritase Syariah Nasional atau melalui kedua belah pihak dengan menggunakan kesepakatan ijab qobul dahulu atau perjanjian baru.

Penyelesaian sengketa ekonomi Non litigasi berasal dari bahasa Inggris yang terdiri dari dua suku kata, yaitu Non dan Litigasi. Non berasal dari kata None yang berarti Tidak atau menolak dan litigasi berasal dari litigation yang berarti proses pengadilan atau jalannya perkara. Namun di Indonesia penyeleseian ini dikenal dengan penyeleseian perkara di luar Pengadilan Agama.

Di Indonesia, Alternatif penyeleseian sengketa sudah di lembagakan dengan lahirnya Undang-Undang Nomor 30 Tentang Arbitrase dan alternatif penyeleseian sengketa. Alternatife penyeleseian sengketa menawarkan beberapa bentuk mekanisme yang fleksibel dengan menerapkan satu atau beberap bentuk mekanisme yang dirancang dan disesuaikan dengan kebutuhan dan 
demikian sengketa diusahakan mencapai putusan final.

Melihat kondisi masyarakat yang sangat membutuhkan dana dengan akad yang menyejahterakan pula, maka perlu hadirnya Bank atau koperasi simpan Pinjam yang nantinya bisa membantu masyarakat umum. Dari sini penulis memaparkan penelitian di KSPPS BTM Mulia Babat yang fokus pada simpan pinjam dan pembiayaan syari'ah. Dimana dengan lahirnya KSPPS ini sangat membantu masyarakat yang membutuhkan dana untuk modal usaha atau yang lainnya dengan akad yang menyejahterakan.

Penerapan praktek akad murabahah di KSPPS BTM Mulia tidak jauh beda dengan Koperasi atau BMT lainnya, sebagaimana prinsip syariah menjelaskan bank sebagai pemberi biaya kepada nasabah atau membeli barang yang dibutuhkan oleh nasabah, lalu menjual dengan margin atau laba yang disepakati. Namun masih banyak nasabah yang masih saja menyelewengkan akad sehingga terjadi wanprestasi seperti angsuran dana macet. Menyikapi hal tersebut KSPPS BTM Mulia Babat mengantisipasi penyelesaian sengketa ekonomi tersebut dengan pendekatan Non litigasi dimana pendekatan ini dimaksud mendamaikan keuda belah pihak sehingga tidak samapai kemeja hijau.

penulisan ini mencoba mengkaji bagaiamana penerapan akad Murabahah dan penyelesaian sengketa ekonomi syariah, apabila ditemukan wanprestasi dari segi kontrak maupun penyelesaian sengketanya. di sisilain sebagai sumbangsi keilmuan dikalangan masyarakat dan akademisi serta bisa dimanfaatkan sebagai acuan ilmu dikalangan akademisi atau Masyarakat umum.

\section{METODE PENELITIAN}

Dalam penelitian ini penulis menggunakan jenis penelitian deskriptif kualitatif. Melalui studi kasus yaitu, penyeleseian sengketa ekonomi syariah, dan penerapan akad Murabahah di KSPPS
BTM Mulia Babat. Mengmpulkan datadata primer mulai penyeleseian sengketa ekonomi, data nasabah, data bank. Data akad, serta data perjanjian baru dan pendukung penelitian di KSPPS BTM Mulia Babat. Penulis lebih fokus kepada penyelesaian dan penerapan akad pada produk-produk ekonomi syariah, melalui pengumpulan data primer, data sekunder, wawancara atau reduksi data di lapanagan. Selanjutnya menganalisa sesuai dengan teori yang ada dalam bab II pada laporan penelitian ini, serta membuat kesimpulan sehingga mudah dipahami oleh diri sendiri dan orang lain.

\section{PEMBAHASAN}

\section{Macam-macam sengketa ekonomi syari'ah}

Perselisihan ekonomi syari'at merupakan ranah sengketa dalam kegiatan bisnis atau perdagangan. Sengketa ekonomin syari'at dapat terjadi sebelum maupun pasca perjanjian disepakati, misalnya mengenai objek perjanjian, harga barang, dan isi perjanjian (Akad). Timbulnya sengketa disebabkan dari beberapa faktor diantaranya;

a. Konflik data konflik ini muncul akibat dari kekurangan berkas, informasi ataupun data-data yang lain, atau isi dari berkas perjanjian yang berbeda.

b. Konflik kepentingan ada 4 faktor dari monflik ini yakni, adanya perasaan atau tindakan yang bersaing, adanya kepentingan subtansi dari para pihak, adanya kepentingan prosuderal, adanya kepentingan psikologi.

c. Konflik Hubungan konflik ini terjadi lantaran hubungan emosional yang kuat, adanya kesalahan presepsi, miskin komunikasi, atau kesalahan komunikasi dan tingkah lagu negatif yang berulang-ulang.

d. Konflik struktur hal ini muncul lantaran adanya pola merusak perilaku atau interaksi, kontrol yang tidak sama, kepemilikan atau 
distribusi sumber daya yang tidak sama, adanya kekuasaan yang geografi, psikologi yang tidak sama, atau faktor-faktor lingkungan yang menghalangi kerja sama.

e. Konflik nilai terjadi disebabkan oleh adanya perbedaan kriteria evaluasi pendapat atau perilaku, adanya perbedaan pandangan hidup ideologi dan agama, adanya penilaian sendiri tanpa memperhatikan penilaian orang lain.

\section{Sebab-sebab terjadinya Sengketa Ekonomi}

Berdasarkan Undang-Undang Nomor 3 tahun 2006 Pasal 49 huruf (i) dimana pasal dan isinya tidak dirubah dalam Undang-Undang Nomor 50 Tahun 2009 Tentang Perubahan Kedua UndangUndang Nomor 7 Tahun 1989 Tentang Peradilan Agama, dalam Undang-Undang tersebut disebutkan bahwa Peradilan Agama bertugas dan berwenang mengadili dan menyelesaikan perkara di tingkat pertama antara orang-orang yang beragama Islam dalam bidang ekonomi syariah $^{8}$, diantaranya :Bank Syariah, Lembaga Keuangan Mikro syariah, Asuransi Syariah, Reasuransi Syariah, Reksadana syariah, Obligasi syariah dan surat berharga berjangka menengah syariah, Sekuritas Syariah, Pembiayaan syariah, Pegadaian Syariah, Dana Pensiun Lembaga Keuangan Syariah, dan Bisnis Syariah $^{9}$. Perkembangan dunia usaha yang menggunakan akad-akad syariah secara signifikan faktanya, mengakibatkan tidak sedikit terjadi sengketa di antara para pelaku ekonomi syariah, sehingga Mahkamah Agung mengeluarkan Peraturan Mahkamah Agung Nomor 14 Tahun 2016 pada tanggal 22 Desember 2016 Tentang Penyelesaian Perkara Ekonomi Syariah. Adapun sebab-sebab

\footnotetext{
${ }^{8}$ Undang-Undang Nomor 3 Tahun 2006 Tentang Peradilan Agama.

${ }^{9}$ Jaih Mubarok, Hukum Ekonomi Syariah Akad Mudharabah (Bandung: fokusmedia, 2013). 102.
}

terjadinya sengketa ekonomi syari'at adalah sebagai berikut;

1. Proses terbentuknya akad disebabkan dari ketidaksepemahaman dalam proses bisnis karena terjebak pada orientasi keuntungan.

2. Akad dan kontrak sulit untuk dilaksanakan

Ada pula sengketa bank syari'ah yang sering terjadi disebabkan adanya pengingkaran, pelanggaran tersebut diantaranya;

a. Kelalaian bank untuk mengembalikan dana titipan nasabah dalam akad wadi'ah.

b. Bank mengurangi nisbah keuntungan nasabah tanpa persetujuan yang bersangkutan dalam akad mudharabah.

c. Nasabah melakukan kegiatan usah yang diharamkan syari'at islam yang bersumber dari dana qirah dan lainlain.

Setiap kegiatan ekonomi syariah pastilah tidak berjalan mulus, pasti terdapat sengketa antara kedua belah pihak baik dari segi akad atau kemacetan angsuran nasabah. Dalam Hukum ekonomi syariah apabila seseorang atau badan hukum yang telah melakukan akad syariah dengan pihak lain, maka antara pihak tersebut telah terjalinnya perikatan. Oleh karena itu, menurut hukum perdata, kesepakatan yang telah direstui para pihak tersebut akan mengikat sebagai undangundang bagi mereka yang membuatnya ${ }^{10}$.

Macam-macam Penyelesaian Sengketa Ekonomi Syari'ah

\section{a. Penyelesaian sengketa Ekonomi Litigasi}

Penyelesaian sengketa ekonomi syariah merupakan kompetensi dan kewenangan Pengadilan Agama yang didasarkan pada Penjelasan point (1) Pasal 49 Undang-Undang Nomor 3

\footnotetext{
${ }^{10}$ Richard Burton simatupang, Aspek Hukum Dalam Bisnis, (Jakarta: Rineka Cipta, 2003), 41.
} 
Tahun 2006 tentang Perubahan Undang-Undang Nomor 7 Tahun 1989 tentang Peradilan Agama, serta ditegaskan kembali dalam Pasal 55 ayat (1) Undang-Undang Nomor 21 Tahun 2008 tentang Perbankan Syariah yang menyatakan apabila terjadi sengketa di bidang perbankan syariah, maka peyelesaian sengketa diajukan ke Pengadilan Agama. Dalam hal ini Pengadilan agama mempunyai hak dan wewenang untuk menerima, mengadili, dan menyelesaikannya ${ }^{11}$.

Sesuai dengan Pasal peraturan Mahkamah Agung Nomor 14 tahun 2016 Tentang Tata Penyeleseian Sengketa Ekonomi Syari'at. Gugatan dalam perkara ekonomi syari'at dapat diajukan secara lisan aau secara tertulis dalam bentuk cetak atau pendaftaran perkara secara elektronik dalam pemeriksaan perkara dengan cara sederhana yang nilainya paling banyak adalah RP. 200.000.000,00 (Dua Ratus Juta Rupiah) yang diselesaikan dengan tata cara dan pembuktian yang sederhana.

Penyelesaian sengketa dengan acara biasa Adalah sengketa ekonomi syari'at dengan acara biasa untyk gugatan biasa berpedoman pada hukum acara perdata yang berlaku kecuali yang telah diatur secara khusus dalam peraturan Mahkamah Agung. Penyelesaian sengketa ekonomi syariat diatur dalam nomor 14 Tahun 2019 Peraturan Mahkamah Agung.

\section{b. Penyeleseian sengketa Non- Litigasi $^{12}$}

Non litigasi berasal dari bahasa Inggris yang terdiri dari dua suku kata, yaitu Non dan Litigasi. Non berasal dari kata None yang berarti Tidak atau menolak dan litigasi berasal dari litigation yang berarti proses pengadilan atau jalannya perkara. Namun di Indonesia penyeleseian ini dikenal

\footnotetext{
11. "Ibid".

${ }^{12}$ Amran, penyelesaian, 46.
}

dengan penyeleseian perkara di luar Pengadilan Agama.

Di Indonesia, Alternatif penyeleseian sengketa sudah di lembagakan dengan lahirnya Undang-Undang Nomor 30 Tentang Arbitrase dan alternatif penyeleseian sengketa. Alternatife penyeleseian sengketa menawarkan beberapa bentuk mekanisme yang fleksibel dengan menerapkan satu atau beberap bentuk mekanisme yang dirancang dan disesuaikan dengan kebutuhan dan demikian sengketa diusahakan mencapai putusan final. Ada beberapa prinsip dalam penyeleseian sengketa ekonomi syari'at yang harus dipegang diantaranya;

1. Prinsip Perdamaian atau (Sulhu) prinsip perdamaian adalah prinsip utama dari segala penyeleseian perkara. Serta prinsip adil juga ditegaskan Allah dalam Surat alHujurat ayat 9. Upaya damai biasanya ditempuh melalui musyawarah (syurah) untuk mencapai Mufakat diantara para pihak yang bersengketa. Dengan Musyawarah yang mengedepankan prinsip-prinsip syari'at diharapkan apa yang menjadi masalah para pihak dapat terseleseikan.

2. Tahkim selain menempuh jalur perdamaian yang dilakukan kedua belah pihak yang berselisih, para pihak juga bisa menggunakan jasa orang ketiga sebagai wasit atau mediator untuk menengahi perselisihan. Institusi formal yang khusus dibentuk untuk menangani perselisihan atau sengketa disebut sebagai arbitrase, yaitu cara penyeleseian sengketa perdata di luar peradilan umum yang didasarkan pada perjanjian arbitrase yang dibuat secara tertulis oleh para pihak yang bersengketa.

\section{Analisis Penerpan Akad Murabahah}

Akad Murabahah secara bahasa dari kata Rabaha yang ditambah alif untuk 
menunjukkaisytirak(Kebersamaan/berseku tu) atau murabahah diartikan "memberi keuntungan atau laba ${ }^{13}$. Secara Istilah yaitu jual beli barang dengan dengan tambahan harga atas dasar harga pembelian pertama dengan jujur atau jual beli barangpada harga asal dengan tambahan keuntungan yang disepakati oleh kedua belah pihak.

Kompilasi Hukum Ekonomi Syariah, mendefinisikan murabahah sebagai suatu jenis pembiayaan saling menguntungkan yangdilakukan oleh pemilik modal dengan pihak yangmembutuhkan melalui transaksi jual beli dengan penjelasan dalam akad bahwa harga pengadaan barang dan harga jual terdapat nilailebih yang merupakan keuntungan atau laba bagi pemilik modaldan pengembaliannya dilakukan secara tunai atau angsur. ${ }^{14}$

Penerapan Akad Murabahah yang ditawarkan di KSPPS BTM Mulia yakni akad murabahah dngan skala besar dan skala kecil ada pula yang menggunakan tambahan akad murabahah bilwakil (wakalah) apa bila pembelian barang diluar jangkauan pemberi biaya, namun bank meminta nota pembelian agar mengetahui harga awal yang nantinya digunakan penjelasan ke calon nasabah ${ }^{15}$. Penulis disini fokus meneliti pada akad murabahah secara umum di KSPPS BTM Mulia Babat, akad Murabahah di BTM Mulia ada beberapa tahapan yakni:

1. Kedua belah pihak antara Pemberi biaya (Muslam Ilaihi) dan Muslam bertemu dan mengucap ijab qobul dimana ijab qobul dimaksudkan untuk pembelian barang dengan akad murabahah, dan muslam ilaihi menjelaskan tentang keadaan barang,

\footnotetext{
${ }^{13}$ Boedi Abdullah dan Beni Ahmad, Metode Penelitian Ekonomi Islam Muamalah, (Bandung: Pustaka Setia, 2014), 129. Lihat juga Ikit dan Artiyanto, Jual Beli Dalam Prespektif Ekonomi Islam, (Yogyakarta: Gava Media,2018), 139.

${ }^{14}$ Kompilasi Hukum Ekonomi Syariah, pasal 20 poin 6.

${ }^{15}$ Wawancara dengan $\mathrm{Bu}$ widyastuti dyah purwandari selaku legal di KSPPS BTM Mulia Babat.
}

harga awal barang dan margin (laba) yang disepakati kedua belah pihak.

2. Setelah terjadi ijab qabul dan keterangan muslam alaihi, baru diarahkan kepada legal (pembuat akad), sebelum akad tertulis, legal mengecek kondisi nasabah dengan kartu cheklist dokumen, apabila sudah dicek dan mendapatkan data falid dan disetujui, selanjutnya

3. Pembuatan Wa'at (perjanjian Pemesanan) apa bila skala kecil maka pembiayaan tidak membutuhkan jaminan, jika akad dengan skala besar diatas 2 juta maka diberlakukan jaminan atau pengikat jaminan, pengajuan perjanjian ini dilakukan saat awal pengajuan dan pemberian uang muka setelah harga dan laba sudah diketahui oleh nasabah.

4. Pembuatan akad Murabahah yang dibuatkan legal yang disaksikan oleh Muslam ilaihi, muslam dan para saksi, setalah akad disetujui selanjutnya;

5. Pembuatan surat kesanggupan angsuran dimana didalam akad murabahah dijelaskan detail dari akad murabahah, baik dari pengertian, barang, harga awal, laba yang disepakati, dan juga ganti rugi apabila terjadi keterlambatan angsuran, setelah ijab qabul sepakat baru ditandatangani kedua belah pihak yaitu nasabah dan juga pemberi persetujuan dari nasabah, selanjutnya pemberi biaya, lalu 3 saksi ${ }^{16}$.

Menurut penulis Penerapan akad Murabahah di KSPPS BTM Mulia ditinjau dari Dasar Hukum Islamdan KompilasiHukum Ekonomi Syariah sudah memenuhi kriteria atau prinsip syariah, dimana calon nasabah dijelaskan terlebih dahulu, kemudian Bank mengecek kelayakan nasabah, setelah mendapat

\footnotetext{
${ }^{16}$ Arsip Akad Murabahah, dan hasil wawancara dengan Legal KSPPS BTM Mulia
} 
persetujuan baru mengajukan pembiayaan dan kemudian dilakukan akad dan kesanggupan angsuran yang ditandatangani kedua belah pihak dan para saksi ${ }^{17}$

Sebagaimana pengertian akad murabahah yakni sistem jual beli yang saling menguntungkan baik nasabah dan pemberi biaya, dimana nasabah di berikan dana/modal sesuai kebutuhan dan bank memberikan kejelasan harga awal dan harga laba yang disepakati oleh kedua belah pihak.

\section{Analisisi Penyelesaian sengketa Ekonomi Syariah di BTM Mulia Babat Lamongan}

Penyelesaian Sengketa Ekonomi syariah Non litigasi merupakan penyelesaian sengketa diluar Pengadilan Agama, Di Indonesia, Alternatif penyeleseian sengketa sudah di lembagakan dengan lahirnya UndangUndang Nomor 30 Tentang Arbitrase dan alternatif penyeleseian sengketa. Alternatife penyeleseian sengketa menawarkan beberapa bentuk mekanisme yang fleksibel dengan menerapkan satu atau beberap bentuk mekanisme yang dirancang dan disesuaikan dengan kebutuhan dan demikian sengketa diusahakan mencapai putusan final. Penyelesaian sengketa ekonomi syariah Non litigasi diantaranya;

a. Prinsip Perdamaian atau (Sulhu).

prinsip perdamaian adalah prinsip utama dari segala penyeleseian perkara. Serta prinsip adil juga ditegaskan Allah dalam Surat al-Hujurat ayat 9. Upaya damai biasanya ditempuh melalui musyawarah (syurah) untuk mencapai Mufakat diantara para pihak yang bersengketa. Dengan Musyawarah yang mengedepankan prinsip-prinsip syariah diharapkan apa yang menjadi masalah para pihak dapat terseleseikan.

\footnotetext{
17 Bisa dilihat dari surat pembuatan akad murabahah
}

\section{b. Tahkim}

Selain menempuh jalur perdamaian yang dilakukan kedua belah pihak yang berselisih, para pihak juga bisa menggunakan jasa orang ketiga sebagai wasit atau mediator untuk menengahi perselisihan. Institusi formal yang khusus dibentuk untuk menangani perselisihan atau sengketa disebut sebagai arbitrase, yaitu cara penyeleseian sengketa perdata di luar peradilan umum yang didasarkan pada perjanjian arbitrase yang dibuat secara tertulis oleh para pihak yang bersengketa.

c. Lembaga Mediasi

Untuk penyelesaian sengketa yang melibatkan lembaga mediasi Mahkamah Agung Republik Indonesia telah menerbitkan Peraturan Mahkamah Agung Republik Indonesia (Perma) Nomor 2 Tahun 2003 tentang Prosedur Mediasi di Pengadilan tanggal 11 September 2003. Mediasi berarti menengahi atau penyelesaian sengketa melalui penengah (mediator). Dengan demikian sistem mediasi, mencari penyelesaian sengketa melalui mediator (penengah) ${ }^{18}$.

d. Sistem Konsolidasi

Konsolidasi (conciliation), dapat diartikan sebagai pendamai atau lembaga pendamai.

Penyelesaian sengketa ekonomi syariah pada akad murabahah yang diterapkan oleh KSPPS BTM Mulia Babat yakni menggunakan asas kekeluargaan, Musyawarah, Perdamaian (Tahkim) antara kedua belah pihak baik Pemberi biaya (Koperasi) dan nasabah.

Dalam menyelesaikan sengketa dengan asas kekeluargaan (Perdamaian) KSPPS BTM Mulia Babat menggunakan tahapantahan sebagai berikut.

1. Bank atau koperasi memberi surat atau memanggil pihak nasabah.

2. Sebelum diadakan akad kembali, pihak legal mengecek kembali data

\footnotetext{
${ }^{18}$ Gunawan Widjaja dan Ahmad Yani, Hukum Arbitrase, (Jakarta :Rajawali Pers,2003),15
} 
nasabah, kemudian nasabah dan bank dipertemukan untuk membahas kesanggupan nasabah dalam mengangsur dana kekurangan.

3. Setelah sepakat berdamai, nasabah menulis surat pernyataan bermatrai 6000 yang isinya menyatakan kesanggupan mengangsur dana. Selanjutnya;

4. Nasabah melakukan pengajuan adendum/ pembuatan kesepakatan baru.

5. Setelah diajukan adendum baru kedua belah pihak berijab qabul kembali dan melakukan akad baru dengan kesepakatan yang telah dibuat keduanya.

6. Setelah dibuatkan akad terbaru, barulah ditandangani akad tersebut, seperti saat akad awal ${ }^{19}$.

Menurut Bapak Basuki Rahmat adalah nasabah KSPPS BTM Mulia Babat sejak tahun 2017, beliau merupakan nasabah yang meminjam dana dengan akad murabahah yang digunakan untuk pembelian tanah. Beliau menjelaskan peminjaman di BTM Mulia sangat membantu dalam pembelian tanah. Disisi lain beliau selaku nasabah yang mengajukan adendum akad. Menurut beliau Penerapan akad di KSPPS BTM Mulia babat sangat transparan dan mudah dipahami, karena nasabah dibekali surat pembuatan akad, disisi lain penulis menanyakan permasalahan yang membuat nasabah melakukan adendum, sesuai hasil wawancara, Bapak Basuki Rahmat menjawab karena keterlambatan pembayaran angsuran yang beliau pinjam saat itu. beliau juga menjelaskan mekanisme penyelesaiannya, menurut beliau tahapan adendum tidak sampai merugikannya, karena koperasi tidak sampai menarik barang atau melelang jaminan, melainkan pemanggilan dan pembuatan surat pernyataan yang isinya

\footnotetext{
19 Wawancara dengan $\mathrm{Bu}$ widyastuti dyah purwandari selaku legal di KSPPS BTM Mulia Babat.
}

kesanggupan pembayaran dan juga siap melelang barang apabila terjadi sengketa kembali, setelah mengisi kesanggupan, beliau menerangkan setelah mengisi pernyataan diarahkan ke legal untuk pengajuan adendum dan pembuatan kesepakatan baru yang ditandangani antara nasabah dan bank dan juga para saksi ${ }^{20}$. Hasil wawancara ini, sesuai dengan penelitian penulis dengan melihat arsip data pembuatan adendum dan surat pernyataan kesanggupan anggsuran serta kesepakatan akad yang sudah diadendumkan.

Menurut Penulis penyelesaian sengketa ekonomi di KSPPS BTM Mulia Babat dalam menyelesaikan sengketa ekonomi syariah, lebih mengedepankan asas kekeluargaan atau perdamaian (Sulhu), dimana kedua belah pihak nasabah dan pemberi pinjaman melakukan kesepakatan baru, sebelum terjadi adendum (perjanjian baru) nasabah mengisi surat pernyataan kesanggupan pembayaran angsuran kemudian mengajukan adendum, setelah pengajuan adendum baru dibuatkan akad murabahah kembali tanpa menambah margin yang disepakati diawal akan tetapi mengikuti surat pernyataan yang ditandangani oleh nasabah.

Penyelesaian dengan perdamaian atau kekeluargaan (sulhu) lebih mengedepankan asas syariah dalam menyelesaikan masalah kedua belah pihak. Prinsip Perdamaian atau (Sulhu) prinsip perdamaian adalah prinsip utama dari segala penyeleseian perkara. Serta prinsip adil juga ditegaskan Allah dalam Surat alHujurat ayat 9. Upaya damai biasanya ditempuh melalui musyawarah (syurah) untuk mencapai Mufakat diantara para pihak yang bersengketa. Dengan Musyawarah yang mengedepankan prinsip-prinsip syariah diharapkan apa yang menjadi masalah para pihak dapat terseleseikan.

\footnotetext{
${ }^{20}$ Wawancara dengan Bapak Basuki Rahmat selaku nasabah yang mengajukan adendum
} 


\section{KESIMPULAN}

Penerapan akad Murabahah yang dilakukan KSPPS BTM Mulia sudah sesuai dengan Asas/ Prinsip Syariah, dimana nasabah mengetahui semua hal yang dibutuhkan pada akad, seperti; keadaan barang, dana pinjaman, harga awal barang, dan juga kesepakatan margi/laba yang disepakati kedua belah pihak.
Penyelesaian sengketa ekonomi syariah di KSPPS BTM Mulia Babat menggunakan jalur Non Litigasi yang mana mengedepankan asas perdamaian, kekeluargaan (Sulhu). Perdamaian yang ditempuh dengan menggunakan musyawarah dan kesepakatan baru., adendum (Perjanjian kesepakatan baru) tanpa menambah margin laba yang disepakati diawal melainkan dengan jaminan yang berada disurat pernyataan yang ditandatangani nasabah.

\section{DAFTAR PUSTAKA}

Inggriani, Anggun., Pembiayaan al-Murabahah pada Bank Mandiri Syariah, (ThesisUniversitas Indonesia, Depok, 2011), 3.

Ikit dan Artiyanto, Jual Beli Dalam Prespektif Ekonomi Islam, (Yogyakarta: Gava Media, 2018), 144 .

Prabowo, A. Bagya., Aspek Hukum Pembiayaan Murabahah pada Perbankan Syariah,(Yogyakarta: UII Press, 2012), 47

Hanik Barokah, Latifatul., Analisis pelaksanaan Akad Murabahah Untuk Pembiayaan Modal Usaha Di Baitul Mall Wa Tamwil Istiqomah Karangrejo Tulung Agung, (Skripsi-IAIN Tulung Agung, 2015), 5.

Suaidi, Amran., Penyeleseian Sengketa Ekonomi Syar'ah (Jakarta: Prenada Media Group), 2018.

Mulyadi, pengadilan agama berwenang memeriksa sengketa ekonomi syari'ah. Kompasia beyond blogging.

Undang-Undang Nomor 3 Tahun 2006 Tentang Peradilan Agama.

Mubarok, Jaih., Hukum Ekonomi Syariah Akad Mudharabah (Bandung: fokusmedia, 2013). 102.

Burton simatupang, Richard,. Aspek Hukum Dalam Bisnis, (Jakarta: Rineka Cipta, 2003), 41.

Abdullah, Boedi dan Beni Ahmad, Metode Penelitian Ekonomi Islam Muamalah,(Bandung: Pustaka Setia, 2014), 129.

Kompilasi Hukum Ekonomi Syariah, pasal 20 poin 6.

Wawancara dengan Bu widyastuti dyah purwandari selaku legal di KSPPS BTM Mulia Babat.

Arsip Akad Murabahah, dan hasil wawancara dengan Legal KSPPS BTM Mulia

Gunawan Widjaja dan Ahmad Yani, Hukum Arbitrase, (Jakarta :Rajawali Pers,2003),15 